\title{
PROSES PENETRASI SOSIAL ANTAR PEMAIN PADA GAME MOBILE LEGENDS
}

\author{
Cornelius Hans Irawan ${ }^{1)}$, Tanty Dewi Permassanty, S.Sos., M.M. ${ }^{2)}$ \\ ${ }^{1}$ Fakultas Sosial Ekonomi, Universitas Surya. \\ email: cornelius.irawan97@gmail.com \\ ${ }^{2}$ Fakultas Sosial Ekonomi, Universitas Surya. \\ email: tanty.dewi@surya.ac.id
}

\begin{abstract}
This study discusses the stage of development of social penetration relationship in Mobile Legends game which is seen through three factors of relationship development. The stage of interpersonal relationship development is the stage where two individuals who have not known each other to have an intimate relationship. Mobile Legends is a mobile game that is played in groups and requires interaction to work together. This interaction can be used to build interpersonal relationships. The theory used in this research is Social Penetration Theory. Social Penetration Theory is used to explain how the development of interpersonal relationships between Mobile Legends players. This research uses qualitative approach with constructivist paradigm. This research method is depth interview, observation, and literature study. The study looks at the stage of relationship development through three factors that influence the escalation of relationships, namely the attitude of trust, supportive attitude, and open attitude between players Mobile Legends. Open attitudes, supportive attitudes, and trust among Mobile Legends players have reached the affective exchange stage, that is, they are already open about personal information, romance, and family.
\end{abstract}

Keywords: Developmental Stage Penetration Theory, Mobile Legends.

of Interpersonal Relationship, Social

\section{PENDAHULUAN}

Saat ini, komunikasi antarpribadi telah berkembang di era digital. Burhan bungin (Bungin, 2006) menjelaskan bahwa komunikasi antarpribadi yang pada awalnya berfokus pada tatap muka, mulai meluas dengan menjadi komunikasi yang dapat menggunakan media. tidak dapat dipungkiri bahwa media baru seperti internet telah menjadi sebuah evolusi bagi komunikasi antarpribadi. Penggunaan internet dalam kehidupan sehari hari bukanlah suatu hal yang asing lagi pada saat ini. Penggunaan media sosial semakin diminati orang pada zaman ini. Media baru telah memberikan kontribusi yang besar dalam perkembangan komunikasi antarpribadi (Hidayat D. , 2012).

Menurut Hidayat, internet membuat komunikasi antarpribadi menjadi lebih mudah tanpa mengenal batasan tempat dan waktu. Orang yang tinggal berjauhan dengan lawan bicaranya dapat menerima pesan dalam hitungan detik saja dengan adanya internet. Hal ini dikarenakan adanya fitur chatting. Dengan adanya fitur tersebut, komunikan dan komunikator tidak perlu lagi bertatap muka. Komunikasi antar sahabat yang tinggal berjauhan bahkan berbeda negara jadi lebih mudah. (Hidayat D. , 2012).

Hidayat (Hidayat D. , 2012) juga menjelaskan bahwa internet telah membawa perubahan dari komunikasi yang sangat terbatas menjadi komunikasi yang luas dan tidak terbatasi telah merubah cara orang berkomunikasi dan beradaptasi menjadi orang yang akrab dengan internet.

Salah satu media yang menggunakan internet adalah video game. Video game merupakan salah satu media baru yang menjadi perhatian pada saat ini. Baran (Baran, 2012) 
menjelaskan bahwa, video game menjadi media yang diminati seluruh kalangan usia dan tidak dibatasi oleh gender.

Hasil signifikan mengenai media yang digunakan untuk mengakses media baru terlihat jelas pada riset yang dilakukan oleh Rachmawati dalam pembukuan tahunan Badan Pusat Statistik tahun 2017 (Rachmawati, 2017), menunjukkan. Data menunjukkan bahwa media yang paling banyak digunakan untuk mengakses internet adalah Telepon genggam/telepon genggam.

Berdasarkan data penggunaan tersebut, peneliti memilih game dengan media telepon genggam sebagai objek penelitian. Game tersebut adalah Mobile Legends. Mobile Legends merupakan permainan aksi dan strategi kompetitif. Game ini dimainkan secara profesional dan sebagai hiburan oleh tujuh juta pengguna yang telah mengunduhnya melalui Google Play Store regional Asia Tenggara (Google Play, 2018). Mobile Legends juga merupakan game nomor satu pada kategori top free games di Google Play. Pada Mobile Legends, pemain memiliki enam puluh hero pilihan untuk membentuk dua tim yang berisikan lima orang pemain per timnya untuk saling beradu strategi.

Selain memiliki fitur yang menyenangkan, Mobile Legends memiliki fitur menarik yang membuat pemainnya dapat bersosialisasi dengan para pemain lainnya. Fitur tersebut adalah fitur chatting dan voice chat. Fitur tersebut memungkinkan pemain untuk saling berkomunikasi dengan pemain lainnya melalui chat box atau dengan berbicara secara langsung. Melalui fitur ini, peneliti ingin meneliti proses penetrasi sosial yang terjadi pada pemain Mobile Legends.

Mobile Legends memungkinkan terjadinya komunikasi antarpribadi diantara pemainnya. Oleh karena itu, peneliti tertarik untuk meneliti mengenai empat tahap penetrasi sosial yang terjadi pada pemain Mobile Legends. Empat tahap itu adalah tahap orientasi, tahap pertukaran penjajakan afektif, tahap pertukaran afektif, dan tahap stabil. Keempat tahap tersebut akan dilihat melalui tiga faktor yang dapat menumbuhkan hubungan antarpribadi, yaitu sikap percaya, sikap suportif, dan sikap terbuka.

Altman dan Taylor (West \& Turner, 2014) menjelaskan bahwa penetrasi sosial merupakan teori yang menjelaskan mengenai proses komunikasi menuju keintiman individu dengan individu lainnya. Bukan sekadar keintiman dalam hal fisik, namun dalam hal emosional dan intelektual, sehingga pasangan individu tersebut berada pada tahap melakukan aktivitas bersama.

\section{KAJIAN LITERATUR \\ Komunikasi Antarpribadi}

Devito (Devito, 2013)

menjelaskan bahwa komunikasi antarpribadi adalah komunikasi yang terjadi antara orang-orang yang saling terhubung. Dalam hal ini komunikasi antarpribadi lebih bersifat diadik atau komunikasi antar dua orang. Meskipun dalam perkembangannya komunikasi antarpribadi sering diperluas cakupannya menjadi kelompok intim kecil, contohnya keluarga.

Devito menjelaskan bahwa, komunikasi antarpribadi sebenarnya merupakan suatu sistem yang terjalin antara dua orang yang saling mempengaruhi. Semakin sering kedua orang terssebut melakukan komunikasi antarpribadi, semakin besar pula pengaruh yang diberikan terhadap satu sama lainnya. Hubungan ini akan terus berlangsung, oleh karena itu terdapat proses didalamnya. Proses tersebut adalah semakin dekat atau semakin jauh.

Seiring perkembangan teknologi, Sumitra (Sumitra, 2015) menjelaskan bahwa terdapat inovasi dalam media online yang menyebabkan munculnya komunikasi antarpribadi secara virtual. Saat ini, inovasi ini disebut dengan media sosial.

Saat ini, bukan hanya media untuk bersosialisasi saja yang mengalami inovasi. Video game juga sudah mengalami perkembangan. Semua game 
yang memiliki fitur multi-player dan berbasis online pasti memiliki fitur chat box didalamnya, bahkan ada beberapa game yang sudah memiliki fitur voice chat juga, sehingga komunikasi dengan sesama pemain menjadi lebih mudah.

\section{Faktor-Faktor yang Menumbuhkan Hubungan Antarpribadi}

Menurut Rakhmat (Rakhmat, 2015) dalam bukunya Psikologi Komunikasi, menuliskan tiga faktor yang menumbuhkan hubungan antarpribadi, yaitu kepercayaan, sikap suportif dan keterbukaan diri. Dalam penelitian ini, peneliti akan menggunakan ketiga faktor untuk menganalisis hubungan antara sesama pemain.

\section{Percaya}

Kepercayaan merupakan faktor penting yang menumbuhkan hubungan antarpribadi. Menurut Rakhmat (Rakhmat, 2015), bila seseorang percaya kepada apa yang diyakini oleh orang lain dan yakin bahwa hal tersebut tidak akan merugikan dirinya, maka dia akan memiliki kecenderungan untuk membuka diri pada dia. Kepercayaan dapat membuat intensitas hubungan antarpribadi semakin tinggi. Percaya berarti telah menitipkan bagian diri pada seseorang yang telah dipercayai. Kepercayaan ini yang menjadi awal dari keterbukaan diri. Semakin tinggi rasa kepercayaan seseorang, semakin tinggi pula keinginan dia untuk membuka dirinya.

\section{Sikap Suportif}

Sikap suportif adalah sikap yang mengurangi sikap defensif dalam berkomunikasi. Sikap defensif dapat terjadi karena adanya faktor-faktor personal seperti ketakutan, kecemasan, yang menyebabkan komunikasi antarpribadi menjadi rusak. Oleh karena itu, orang yang bersikap defensif akan lebih sering untuk menangkal setiap masukan dari orang lain dalam berkomunikasi dari pada bersikap untuk mendengarkan dan memahami pesan yang disampaikan oleh orang lain (Rakhmat, 2015).

\section{Sikap Terbuka}

Keterbukaan diri menurut Rakhmat yang dikutip oleh Rhosyidah (Rhosyidah, 2015) adalah tanggapan mengenai situasi yang sedang dialami dengan memberikan informasi mengenai masa lalu yang berkaitan sebagai tanggapan untuk saat ini. Semakin terbuka dia, artinya dia semakin dekat dengan lawan bicaranya. Keterbukaan diri merupakan jantung dari komunikasi antarpribadi yang menjadi cara bagi orang untuk mengetahui apa yang terjadi pada diri manusia (Kadarsih, 2009).

\section{Teori Penetrasi Sosial}

Teori penetrasi sosial digunakan untuk memahami kedekatan hubungan antar dua orang. Hubungan setiap orang sangat bervariasi dalam penetrasi sosial mereka. Menurut Altman dan Taylor (West \& Turner, 2014), penetrasi sosial merupakan lintasan yang harus dilalui untuk mencapai sebuah kedekatan dalam berhubungan.

\section{Lapisan Hubungan : Analogi Bawang}

Sebelum menuju kepada proses keterbukaan diri, Altman dan Taylor (West \& Turner, 2014) mengumpamakan kepribadian manusia seperti lapisan bawang. Lapisan terluar merupakan citra publik atau informasi yang dapat dilihat secara langsung, seperti bentuk fisik, nama, dan umur. Lapisan citra publik akan terkelupas saat dia mulai membuka informasi yang lebih dalam dari sekadar informasi umum.

Jika kedua individu mulai saling terbuka, hal tersebut dinamakan resiproritas. Resiproritas merupakan proses Dimana keterbukaan diri membawa orang lain untuk ikut terbuka. Resiproritas sangat baik untuk hubungan yang masih baru maupun hubungan yang sudah lama. Keintiman tidak akan bisa didapatkan tanpa adanya resiproritas. 
Penetrasi sosial dapat dilihat dengan dua dimensi, yaitu kedalaman (depth) dan keluasan (breadth) yang dilihat berdasarkan topik perbincangan. Kedalaman dan keluasan ini memiliki pengaruh lebih besar pada lapisan yang lebih dalam dari pada lapisan terluar. Contohnya perubahan fisik memberikan pengaruh yang lebih kecil dari pada mengutarakan perasaan terhadap seseorang.

\section{Tahap Proses Penetrasi Sosial}

Menurut Altman dan Taylor (West \& Turner, 2014), terdapat 4 tahap dari proses penetrasi sosial, yaitu sebagai berikut :

\section{Tahap Orientasi}

Merupakan tahap awal dalam proses penetrasi sosial. Pada tahap ini, hanya sebagian kecil diri orang yang orang lain dapat lihat. Percakapan yang terjadi biasanya bersifat basa-basi dan hanya menunjukkan informasi umum seperti data diri.

Pada tahap ini juga, orang lebih cenderung untuk berdiam diri dari pada memberikan kritik, karena hal tersebut akan dianggap aneh oleh orang lain. Kedua pihak yang sedang melakukan penetrasi sosial akan berusaha menjauhkan diri dari konflik agar mereka memiliki kesempatan untuk lanjut ke tahap selanjutnya. Menurut Altman dan Taylor yang dikutip oleh Wulandari (Wulandari, 2015), jika pada tahap ini kedua orang yang bersangkutan merasa telah mendapatkan interaksi yang dibutuhkan, mereka akan melanjutkan penetrasi ke tahap berikutnya.

\section{Tahap Pertukaran Penjajakan Afektif}

Tahap ini merupakan tahapan ekspansi awal dari informasi dan perpindahan ke tingkat pengungkapan yang lebih dalam dari tahap pertama. Dalam tahap ini, dua individu sudah menuju ke tahap menanyakan atau memahami hal yang disukai atau kesenangan masing-masing, seperti kesenagan dari segi makanan, musik, lagu, dan hobi.

Seseorang mulai menunjukkan diri mereka pada orang lain. Kepribadian yang pada awalnya merupakan hal pribadi, sekarang menjadi hal yang umum. Pada tahap ini, Orang mulai menggunakan pilihan katakata atau ungkapan yang bersifat lebih personal. Komunikasi yang terjalin juga menjadi lebih spontan karena kedua individu merasa sudah terbiasa dengan lawan bicaranya, mereka juga lebih leluasa dalam mengungkapkan sesuatu yang mungkin akan menyebabkan hubungan yang sudah terjalin menjadi rusak. Perilaku berupa sentuhan dan ekspresi emosi juga mengalami peningkatan pada tahap ini. Tahap ini merupakan tahap penting yang menentukan jalan ke hubungan selanjutnya atau terhenti.

\section{Tahap Pertukaran Afektif}

Pada tahap ini terjadi peningkatan informasi yang lebih bersifat pribadi, seperti informasi mengenai pengalamanpengalaman pribadi masing-masing. Jadi, dua individu tersebut sudah mulai membuka diri dengan informasi diri yang sifatnya lebih pribadi. Kesediaan menceritakan tentang masalah pribadi juga termasuk. Dengan kata lain, kedua individu tersebut sudah mulai berani mencurahkan isi hatinya.

Tahap ini juga ditandai dengan adanya tindakan yang menunjukkan perbedaan pendapat pada hal tertentu yang menyebabkan terjadinya saling kritik. Namun, belum berpotensi dalam mengancam atau merusak hubungan yang sudah terjalin. Pada tahap ini, tidak ada hambatan untuk saling mendekatkan diri. Namun, menurut Wulandari (Wulandari, 2015), masih banyak orang yang berusaha untuk melindungi diri mereka dengan tidak mengungkapkan informasi diri yang terlalu sensitif.

\section{Tahap Pertukaran Stabil}

Tahap terakhir adalah lapisan inti yang disebut sebagai pertukaran yang stabil. Pada tahap ini, Altman dan 
Taylor (West \& Turner, 2014) menjelaskan bahwa komunikasi yan terjalin sudah bersifat efisien. Makna dalam percakapan yang ada jelas dan tidak ambigu. sifatnya sudah sangat intim dan memungkinkan kedua individu untuk memprediksikan tindakan-tindakan dan respon masingmasing individu dengan baik. Informasi yang dibicarakan sudah sangat dalam dan menjadi intim, seperti soal nilai, konsep diri, atau perasaan emosi terdalam. Kedua individu telah masuk kedalam tahap saling mengerti dan memahami perasaan masing-masing.

\section{Mobile Legends}

Mobile Legends merupakan game mobile yang bergenre multiplayer online battleground arena (MOBA) (Moonton). Mobile Legends telah menjadi game nomor satu pada kategori top free games di Google Play. Game ini dimainkan oleh sepuluh orang pemain. Sepuluh pemain tersebut terbagi menjadi dua tim. Kedua tim memiliki tujuan untuk menghancurkan benteng (tower) lawan untuk memenangkan game ini.

Saat ini Mobile Legends telah memiliki enam puluh hero dengan berbagai tipe, yaitu tank, fighter, mage, assasins, marksman, dan support. Setiap hero memiliki fungsi dan kegunaannya masing-masing dalam tim. Pengaturan serta pemilihan hero sangat berpengaruh bagi kesuksesan tim dalam menghancurkan benteng lawan.

Mobile Legends memungkinkan pemainnya untuk bermain dengan orang lain yang belum ia kenal ataupun bermain dengan orang yang sudah dikenal. Game ini sangat membutuhkan kerja sama untuk mencapai kemenangan. Oleh karena itu dibutuhkan komunikasi yang baik antara setiap pemainnya dalam satu tim.

Oleh karena itu, Mobile Legends memiliki fitur berkomunikasi yang memungkinkan pemain untuk berbicara dalam game menggunakan voice chat maupun text chat. Text chat dapat dilakukan pada saat sedang bermain maupun pada menu awal. Sedangkan voice chat hanya bisa dilakukan pada saat sedang bermain.

\section{METODE PENELITIAN}

Pendekatan kualitatif dengan metode studi kasus digunakan dengan tujuan untuk memberi gambaran secara cermat mengenai individu atau kelompok tertentu tentang keadaan dan gejala yang terjadi, yang dimaksud individu dalam penelitian ini adalah Pemain Mobile Legends. Tujuan utama adalah untuk menggambarkan realitas yang sedang terjadi. Dalam hal ini, peneliti ikut aktif dalam memilih dan menentukan jenis data yang diinginkan, maka peneliti akan turun ke lapangan. Peneliti ikut bermain Mobile Legends untuk melihat dan mengamati mengenai pemain Mobile Legends tersebut, melihat bagaimana interaksi dan hubungan yang terjadi di antara pemain Mobile Legends. Karena itu riset ini bersifat subjektif sehingga hasilnya lebih dikhususkan untuk melihat salah satu realitas, bukan melihat secara menyeluruh.

\section{Metode Pengumpulan Data}

Dalam penelitian kualitatif, hasil data penelitian sangat bergantung pada kemampuan peneliti dalam menghayati dan menyatu dengan lingkungan yang sedang ia teliti (Yusuf, 2014). Kemampuan tersebut dapat membuat peneliti untuk menggali lebih dalam lagi mengenai data yang benar-benar ia inginkan. Tentu saja data yang dikumpulkan oleh peneliti tidak akan pernah berhenti hingga peneliti memiliki data yang benar-benar sesuai dengan apa yang diinginkan. Metode pengumpulan data yang digunakan dalam penelitian ini meliputi;

\section{Wawancara}

Pada penelitian ini, peneliti menggunakan teknik telephone interview dan e-mail interview. Salah satu keuntungan dari telephone interview adalah memungkinkan peneliti untuk memiliki materi penelitian dan persiapan saat melakukan wawancara 
(Farooq, 2015). Meskipun telephone interview memiliki kekurangan seperti tidak dapat melihat gestur atau bahasa tubuh dari narasumber yang sedang diwawancara. Begitu juga dengan e-mail interview. Meho (Meho, 2006) juga mengatakan bahwa keterbatasan dari email interview juga tidak dapat melihat mimik wajah narasumber yang sedang diwawancarai meskipun pada e-mail memiliki fitur seperti emoticon. Namun, e-mail interview efektif untuk menekan pengeluaran jika narasumber yang dibutuhkan berada pada kota bahkan negara yang berbeda.

\section{Observasi}

Observasi adalah suatu cara pengumpulan data dengan pengamatan langsung dan pencatatan secara sistematis terhadap obyek yang akan diteliti. Jenis observasi yang digunakan adalah observasi partisipan. Observasi partisipan adalah metode observasi di mana peneliti juga ikut ambil bagian sebagai partisipan, ikut serta dalam kegiatan yang dilakukan oleh kelompok yang diteliti (Kriyantono, 2006). Dalam penelitian ini peneliti membuat akun game Mobile Legends untuk melakukan observasi secara langsung dan melihat bagaimana eskalasi hubungan dan interaksi yang terjadi di antara pemain game Mobile Legends. Peneliti juga membuat akun WhatsApps untuk ikut tergabung dalam grup yang telah dibuat oleh pemain Mobile Legends.

\section{Pengumpulan Sumber Pustaka}

Untuk melengkapi penelitian ini, peneliti juga menggunakan data-data sekunder yang didapatkan dari berbagai sumber literatur dan dokumen, seperti buku, jurnal, skripsi, makalah, dan internet.

Teknik Analisis Data

\begin{tabular}{|c|c|c|}
\hline Analisis & $\begin{array}{c}\text { Isi } \\
\text { Analisis }\end{array}$ & $\begin{array}{c}\text { Pengumpulan } \\
\text { Data }\end{array}$ \\
\hline $\begin{array}{c}\text { Sikap } \\
\text { percaya } \\
\text { antara }\end{array}$ & $\begin{array}{c}\text { Tahap } \\
\text { proses } \\
\text { penetrasi }\end{array}$ & $\begin{array}{c}\text { Wawancara } \\
\text { dan observasi }\end{array}$ \\
\hline
\end{tabular}

\begin{tabular}{|c|c|c|}
\hline $\begin{array}{c}\text { pemain } \\
\text { Mobile } \\
\text { Legends }\end{array}$ & sosial & \\
\hline Sikap & & \\
suportif & Tahap & \\
antara & proses & Wawancara \\
pemain & penetrasi & dan observasi \\
Mobile & sosial & \\
Legends & & \\
\hline Sikap & & \\
terbuka & Tahap & \\
antara & proses & Wawancara \\
pemain & penetrasi & dan observasi \\
Mobile & sosial. & \\
Legends & & \\
\hline
\end{tabular}

\section{Reduksi Data}

Peneliti akan menggolongkan, mengarahkan, dan membuang data hasil wawancara serta observasi yang tidak diperlukan. Kemudian melakukan pengorganisasian data agar hasil akhir dari data yang didapat bisa ditarik dan diverivikasi. Reduksi data yang dilakukan dalam penelitian ini bertujuan untuk membuat ringkasan, menelusuri tema dan menulis catatan yang diperlukan.

\section{Penyajian Data}

Setelah mereduksi data, peneliti akan menyajikan data akhir. Penyajian data akan dibuat dalam uraian yang dikombinasikan dengan tabel. Pada langkah ini, peneliti berusaha menyusun data yang relevan sehingga informasi yang didapat bisa disimpulkan serta bermakna untuk menjawab masalah penelitian.

\section{Menarik Simpulan}

Tahap ini merupakan tahap penarikan kesimpulan dari semua data yang telah diperoleh sebagai hasil dari penelitian. Pada saat pengumpulan data, seorang penganalisis data kualitatif mulai mencari pola-pola, mencatat keteraturan, penjelasan, alur sebab akibat, dan mencari arti atau makna. Kesimpulan yang awalnya jelas akan menjadi lebih terperinci. 


\section{HASIL DAN PEMBAHASAN}

\section{Perkembangan \\ Hubungan \\ Antarpribadi Pemain Mobile Legends}

Tahap perkembangan hubungan antarpribadi antara pemain Mobile Legends akan dideskripsikan menggunakan empat tahap dalam penetrasi sosial menurut Altman dan Taylor, yaitu tahap orientasi, pertukaran penjajakan afektif, pertukaran afektif, dan pertukaran stabil. Keempat tahap tersebut akan digunakan untuk menganalisis tiga faktor yang menumbuhkan hubungan antarpribadi menurut Rahhmat dalam Psikologi Komunikasi. Ketiga faktor tersebut adalah sikap percaya, suportif, dan terbuka.

\section{Sikap Percaya antara Pemain Mobile Legends}

Pada tahap pertama, yaitu tahap orientasi, hanya sebagian kecil diri orang yang orang lain yang dapat dilihat. Percakapan yang terjadi biasanya bersifat basa-basi dan hanya menunjukkan informasi umum seperti data diri. Pada perkembangan hubungan antara pemain Mobile Legends, tahap ini diawali dengan komunikasi untuk mengajak orang lain untuk bermain, dan berbicara seputar informasi Mobile Legends. Percakapan yang dilakukan hanya sebatas mengajak bermain dan perbincangan mengenai hero baru yang muncul di Mobile Legends.

Tahap kedua adalah pertukaran penjajakan afektif. Tahap ini merupakan tahapan ekspansi awal dari informasi dan perpindahan ke tingkat pengungkapan yang lebih dalam dari tahap pertama. Dalam tahap ini, dua individu sudah menuju ke tahap menanyakan atau memahami hal yang disukai atau kesenangan masing-masing, seperti kesenagan dari segi makanan, musik, lagu, dan hobi.keempat infoman sudah mulai saling mengenal. Mereka mulai menaruh kepercayaan dengan cara menunjukkan dan mengetahui hobi setiap informan di dalam komunikasi. Bukan hanya mengetahui hobi, informan juga sudah tidak memperdulikan norma. Informan sudah mulai menggunakan bahasa kasar saat berkomunikasi dan sudah tidak merasa sungkan akan setiap kata yang diucapkan. Informan sering menggunakan kata umpatan untuk mengungkapkan kekesalan diri sendiri.

Tahap ketiga merupakan tahap pertukaran afektif. Pada tahap ini terjadi peningkatan informasi yang lebih bersifat pribadi, seperti informasi mengenai pengalaman-pengalaman pribadi masing-masing. Jadi, dua individu tersebut sudah mulai membuka diri dengan informasi diri yang sifatnya lebih pribadi. Kesediaan menceritakan tentang masalah pribadi juga termasuk. Dengan kata lain, kedua individu tersebut sudah mulai berani mencurahkan isi hatinya. Pada tahap ini keempat informan sudah mulai menunjukkan kedekatannya dengan memberikan informasi pribadi. Jika dilihat lagi melalui tiga faktor yang menumbuhkan sikap percaya, ketiga faktor tersebut sudah terpenuhi dalam tahap ketiga ini.

\section{Sikap Suportif yang Terbentuk Antara Pemain Mobile Legends}

Tahap pertama, adalah tahap orientasi. Tahap ini adalah interaksi awal, hanya sedikit bagian dari diri individu yang terbuka untuk orang lain. Komunikasi yang terjadi pun hanya bersifat impersonal dan basa-basi. Pada tahap ini, masih terlihat bentuk dukungan yang diberikan masih bersifat wajar dan tidak terdapat emosi didalamnya. Tahap ini informan 3 hanya bermaksud memberi masukan agar anggota timnya lebih bervariasi dalam menggunakan berbagai hero yang ada pada Mobile Legends. Dukungan yang diberikan msih bersifat umum dan belum menuju kepada dukungan yang mengarah ke perorangan.

Tahap kedua adalah pertukaran penjajakan afektif. Keemat informan sudah merasa tidak perlu menggunakan kata-kata yang umum. Tidak lagi melihat aturan yang baik dan benar saat berkomunikasi. Mereka sudah 
menunjukkan diri mereka masingmasing sehingga komunikasi sudah lebih santai. Terlihat dengan penggunaan kata kasar dalam beberapa kalimat seperti "kek taek ancene, tai tai". Bentuk dukungan yang diberikan juga sudah mulai mendalam hingga perasaan umum saat sedang mengalami kekesalan.

Tahap ketiga adalah pertukaran afektif. Tahap ini bisa dikategorikan sebagai interaksi yang lebih santai dan tanpa beban, komunikasi juga lebih sering spontan dalam memberikan jawaban. Pada tahap pertukaran afektif mulai muncul persahabatan yang dekat atau hubungan yang lebih intim. Pada tahap ini terlihat informan 4 mencoba untuk membuat informan 3 tidak merasa bersalah. Informan 4 berusaha menenangkan informan 3 yang merasa bersalah dengan menyalahkan keadaan. "Kamu gak salah kok ndo, memang waktunya pensi ja" (informan 4). Pada komunikasi selanjutnya, informan 3 yang mencoba untuk memberi dukungan kepada informan 4 agar ia tidak menyerah. "Pensi opo, ojo menyerah. Mayhem ae biar hepi." (informan 3). Terlihat bahwa informan 3 berusaha mendukung informan 4 dengan menyarankan untuk bermain mode mayhem di Mobile Legends.

\section{Sikap Terbuka antara Pemain Mobile Legends}

Tahap pertama adalah orientasi. Informan menjelaskan bahwa awal-awal bertemu, topik percakapan yang sering dibicarakan adalah mengenai hal yang masih berhubungan dengan game Mobile Legends. Bentuk percakapan masih dikategorikan sebagai percakapan basa-basi. Belum ada informasi pribadi yang dibicarakan. Hal tersebut diperkuat oleh informan lain yang juga berkata bahwa topik komunikasi yang dibicarakan masih pada tahap umum dan belum menyangkut masalah pribadi.

Tahap kedua adalah pertukaran penjajakan afektif. Pada tahap ini, informan mulai mengetahui keseharian dari informan lainnya. Terlihat informan mengatakan "Tidur pak. Sepi rek malming...". Hal tersebut menunjukkan bahwa informan sudah mengetahui kegiatan yang dilakukan oleh anggota timnya pada hari sabtu dan minggu. Melalui observasi yang dilakukan, peneliti mengetahui bahwa terdapat informan yang tidak pernah muncul pada grup chat WhatsApps pada hari sabtu dan minggu karena informan tersebut sedang meluangkan waktu dengan pasangannya selama dua hari penuh dan tidak bisa diganggu. Kalaupun informan tersebut memainkan Mobile Legends, pasti ia bermain dengan pasangannya.

Tahap ketiga adalah pertukaran afektif. Berdasarkan informasi yang diberikan, informan menganggap pembicaraan pribadi lebih santai. Ia sudah bisa menggunakan topik pribadi sebagai bahan candaan. Hal tersebut terlihat saat informan menggunakan topik pribadi hubungan asmara kepada informan lainnya sebagai bahan pembicaraan. Informan juga terlihat tidak tersinggung dan merasa sudah biasa dengan informan lain yang sering memberikan candaan yang diluar batas wajar. Meskipun beberapa informan merasa hal tersebut tidak wajar, tapi dia sudah terbiasa dengan sikap informan lainnya, sehingga tidak menjadi masalah. Seperti yang dikatakan oleh seorang informan, "untung aku orange slow jadi wes biasa.".

\section{KESIMPULAN}

Game Mobile Legends merupakan game yang membutuhkan kerjasama antara setiap pemainnya. Semakin kompak suatu tim, semakin besar pula tingkat persentase kemenangan yang akan dihasilkan. Melalui game Mobile Legends, peneliti melakukan penelitian mengenai tahap perkembangan hubungan dengan menggunakan teori penetrasi sosial yang dilihat berdasarkan tiga faktor yang menumbuhkan hubungan antarpribadi, yaitu sikap percaya, sikap suportif, dan sikap terbuka. Berdasarkan penjabaran dari bab analisis dan pembahasan, dapat 
diambil kesimpulan dari penelitian ini, yaitu :

\section{Kepercayaan}

Kepercayaan yang terbentuk antara pemain Mobile Legends telah memasuki tahap pertukaran afektif. Keempat informan sudah saling percaya dengan memberikan informasi pribadi yang berdasar kepada munculnya rasa percaya. Keempat informan mengatakan bahwa mereka telah mempercayai temannya sehingga mereka mau saling bertukar informasi yg bersifat pribadi.

\section{Sikap Suportif}

Sikap suportif antara pemain Mobile Legends telah memasuki tahap pertukaran afektif. Dimana keempat informan sudah saling memberikan dukungan dalam hal pribadi, seperti pendidikan, pekerjaan, dan asmara.

\section{Sikap Terbuka}

Keterbukaan diri dalam komunikasi antarpribadi yang terjadi di antara pemain Mobile Legends ada pada tahap pertukaran afektif, di mana pada tahap ini keempat informan mulai membicarakan hal-hal yang bersifat pribadi seperti masalah pendidikan, pekerjaan, dan asmara.

Dari ketiga faktor yang dapat menumbuhkan hubungan antar pribadi, ketiganya hanya mencapai tahap pertukaran afektif. Hal tersebut disebabkan karena hubungan yang terjalin antara pemain Mobile Legends baru berjalan selama sepuluh bulan. Hubungan yang terjalin tidak dapat mencapai tahap stabil yang bisa saling memahami satu sama lain.

\section{REFERENSI}

Baran, S. J. (2012). Pengantar Komunikasi Massa Melek Media dan Budaya. Jakarta: Penerbit Erlangga.

Budyatna, P. D. (2011). Teori Komunikasi AntarPribadi. Jakarta: Kencana.
Bungin, P. D. (2006). Sosiologi Komunikasi. Jakarta: Kencana.

Devito, J. A. (2013). The Interpersonal Communication. New Jersey: Pearson Education.

Farooq, M. B. (2015). Qualitative telephone interviews: Strategies for success. Waikato Management School Student Research.

Google Play. (2018, Mei 14). Mobile Legends. Retrieved from Google Play:

https://play.google.com/store/ap ps/details?id=com.mobile.legen $\mathrm{ds} \& \mathrm{hl}=$ in

Hidayat, D. (2012). Komunikasi AntarPribadi dan Medianya. Yogyakarta: Graha Ilmu.

Hidayat, D. N. (2002). Metodologi Penelitian dalam Sebuah "MultiParadigm Science". Mediator, 197-220.

Kadarsih, R. (2009). Teori Penetrasi Soial dan Hubungan Interpersonal. Jurnal Dakwah, 53-66.

Kriyantono, R. (2006). Teknik Praktis Riset Komunikasi. Jakarta: Kencana Prenada Media Group.

Meho, L. L. (2006). A Metodological Disscusion. Journal of the American Society for Information Science and Technology.

Moonton. (n.d.). Mobile Legends. Retrieved from Mobile Legends: https://www.mobilelegends.com I

newzoo. (2017). The Indonesian Gamer - Key Consumer Insight. Retrieved from newzoo.com: 
https://newzoo.com/insights/info graphics/the-indonesian-gamer2017/

Rachmawati, Y. (2017). Statistik Pemuda Indonesia 2017. Jakarta: Badan Pusat Statistik.

Rakhmat, J. (2015). Psikologi Komunikasi. Bandung: PT Remaja Rosdakarya.

Rhosyidah, K. (2015). Pengaruh Keterbukaan Diri (Self Disclosure) Terhadap keterampilan Komunikasi Interpersonal Menantu Perempuan pada Ibu Mertua di Daerah Karanganyar Probolinggo. Universitas Islam Negri Malang, 141.

Sumitra, B. (2015). Keintiman Komunikasi Interpersonal Termediasi Melalui New Media (Studi Fenomenologi pada
Pasangan Jarak Jauh).

Universitas Sultan Ageng

Tirtayasa, 160.

West, R., \& Turner, d. L. (2014). Pengantar Teori Komunikasi Analisis dan Aplikasi. Jakarta: Salemba Humanika.

Wood, A. F., \& Smith, M. J. (2004). Online Communication: Linking Technology, Identity, \& Culture (Routledge Communication Series). English: Routledge.

Wulandari, T. A. (2015). Memahami Pengembangan Hubungan Antarpribadi Melalui Teori Penetrasi Sosial. Majalaj Ilmiah Unikom, 103-110.

Yusuf, P. D. (2014). Metode Penelitian Kuantitatif, Kualitatif \& Penelitian Gabungan. Jakarta: Kencana. 
